\title{
Criminological Description of the Person Dealing With Forged Documents
}

\section{Gayrat Okmirzaevich Ermatov}

Acting Associate Professor, Candidate of Legal Sciences, Department of Criminal law, Criminology and Fight against Corruption, Tashkent State Law University

germatov@mail.ru

\begin{abstract}
Crime is a very complex social phenomenon. In reality, it consists of a set of different acts of individual criminal behavior. These acts are performed by living people, and each has its own unique meaning. However, it is possible and necessary to scientifically study and analyze various crimes and the individual subjects who committed them. The means of such scientific analysis and generalization is the study of the offender's personality as a "social type" [1]. The study of the identity of offenders not only deepens our knowledge of the perpetrators of a particular type of crime, but is also important in our practical work in preventing those types of crimes.
\end{abstract}

Keywords: Article, Criminal Code, official documents, stamps, seals, letterheads, honesty, purity and patience.

Article Received: 10 August 2020, Revised: 25 October 2020, Accepted: 18 November 2020

\section{Introduction}

In the system of crimes against the order of the authorities, public authorities and public associations, the crime of illicit handling of documents, stamps, seals, letterheads is one of the most common crimes that undermines the governance of the state and society.

Having studied the criminal cases of 500 people convicted in 300 criminal cases under Article 228 of the Criminal Code of the Republic of Uzbekistan and their criminological characteristics, we came to the conclusion that persons who illegally work with documents, stamps, seals or forms and those who commit crimes against public order also have similarities with personality. Common to all offenders is that the psychophysiological qualities of a person are only the material basis for the formation of his personality, and from the point of view of social qualities, the formation of his personality is associated with his interaction with the social environment surrounding this person [2. 1819].

The Main Findings and Results
The peculiarity of the person dealing illegally with a document, stamp, seal or letterhead is that the perpetrators of such crimes do not have the excitement of an individual mental state, the intensity of emotional excitement, committing a crime in a state of emotional excitement, affecting or transcending defense [3. 104]. The commission of such a crime is the effect of adverse events due to the weakness of the subject's will. Hence, the cause of the crime is a mental and volitional condition related to two factors, namely the negative impact on the environment and the inability to satisfy one's goal in a lawful manner due to a lack of will.

The overwhelming majority of criminals convicted under Article 228 of the Criminal Code, which we investigated, are persons with higher or secondary specialized education. Although crimes against the person, crimes against public order and public safety accounted for a very small proportion of persons with higher or secondary specialized education, almost half of the analyzed criminals were persons with higher and secondary specialized education. In particular, when we analyzed the criminal 
cases of 500 people convicted under Article 228 of the Criminal Code, $22 \%$ of them had a higher education, $26 \%$ had a specialized secondary education, $49 \%$ had a secondary education and $2.7 \%$ did not have a secondary education. Why almost half of the analyzed offenders are people with higher and secondary specialized education? Lack of higher or secondary specialized education, a frivolous attitude to their duties, ignorance of the laws, a high level of kinship, disregard for laws, etc. are also very common among persons with higher and secondary specialized education. Moreover, everything is possible for officials in the post-Soviet era, only those who could not get rid of the concept of dependence, from the idea that the state plan could be carried out, commit this crime. They don't even consider their actions to be criminal.

According to the results of our research, the heads of enterprises, institutions and organizations are liable under Article 209 of the Criminal Code of the Republic of Uzbekistan for falsification of documents, stamps, seals or letterheads. An example is the criminal case of M., which was heard in the Mirzo Ulugbek district court of Tashkent.

M applied orally to A, an accountant at the Tashkent State Medical Institute, asking forged certificate in the name of her husband B., his annual income to become an electrician at the 2nd Tashkent State Medical Institute in order to receive a pension from the "Yalangach ota" mahalla for his two children under the age of 16 . After that, at the verbal request of $\mathrm{N}$, who works as an accountant in the accounting department at the 2nd Tashkent State Medical Institute, M.'s husband B got a fake certificate stating that he works as an electrician at the 2nd Tashkent State Medical Institute. $M$ brought a child allowance for a year on the basis of this act and was prosecuted under Article 228, Part 3 of the Criminal Code of the Republic of Uzbekistan.
The court correctly convicted them under Article 228 (2) (b) of the Criminal Code of the Republic of Uzbekistan [4].

It is unfortunate that almost half of the crimes analyzed are committed by persons with higher and secondary special education. In our view, the task is to ensure that professionals working in enterprises, institutions and organizations strictly adhere to the law, to educate them in the spirit of working only within the scope of their duties, to perform serious tasks to raise their legal awareness.

One of the main reasons why most of the crimes under analysis are committed by persons with higher and secondary special education is that the use of reference forms in the enterprise, institution, organization is not well established. Because any reference of a particular enterprise must be stamped.

Another feature of the crime of forgery of documents, stamps, seals, blanks is that almost all of them are first-time convicts.

According to our research, $96 \%$ of those convicted are first-time offenders. Only $4 \%$ of them are former convicts. What is the reason for the very low number of recidivism in this crime? These $4 \%$ of convicts are also convicted of other crimes (except for Articles 227-228 of the Criminal Code of the Republic of Uzbekistan). We did not find any of the persons previously convicted under Article 228 of the Criminal Code of the Republic of Uzbekistan among the persons we studied. In our view, perpetrators of crimes against the person and other acts of violence use falsification of a document if the degradation of the person has become a dangerous feature to achieve their goals. Many of them are individuals who intend to do good to someone by breaking the law. It is true that the amount of falsification of a document, a large number of looters of property, or a large amount of damage or loss is very rare among the persons we have studied.

$44 \%$ of the individuals we surveyed were mainly individuals who falsified 
official documents (certificates) in order to receive benefits and similar entitlements to low-income families. In the complex conditions of the transition to a market economy, it is much more difficult for people to adapt to new conditions and get rid of the mood of dependence. In such a complex environment, corruption among government officials in the process of forming various forms of ownership, in some cases some illegal actions in the field of privatization of state property, leads to the formation of such views as the use of illegal means to satisfy personal needs. Sometimes some officials working in government agencies try to take advantage of the shortcomings in social relations that have not yet matured in society by gathering close relatives in order to accumulate wealth, instead of caring for their subordinates and carrying out reforms with honesty, purity and patience. Some categories of ordinary people who see this situation try to satisfy their needs in legal and illegal ways.

The main way to prevent the crime under analysis is to establish strict discipline in enterprises, institutions, organizations, that each employee performs his duties honestly and conscientiously.

When comparing the age of those convicted for the crime under analysis, the majority are those between the ages of 40 and 50 at the time of the crime.

Many authors who have studied various criminological aspects of crimes have noted that the number of such crimes decreases as people get older. But in the crimes we are investigating, the opposite is true. That is, as people get older, the number of such crimes increases.

In Article 228 of the Criminal Code of the Republic of Uzbekistan and other crimes, the total number of people prosecuted for crimes is as follows:

Despite the fact that the law stipulates that the age of the subject of this crime is sixteen years, we have not encountered a single criminal case of a person who committed this crime as a minor. Of the 500 people surveyed, $17 \%$ were between the ages of 20 and 30, depending on their age at the time of the crime; those aged 30 to 40 years - 34\%; those between the ages of 40 and 50 make up $36 \%$. From the age of 50 , the number of such crimes has decreased. In particular, $15 \%$ of all individuals we surveyed were over the age of 50 at the time of the crime. The decrease in the number of crimes committed by people over the age of 50 may be related to the decrease in the number of people working in enterprises, institutions and organizations at this age. In addition, many people of this age have reduced their life worries and refrain from illegal activities.

As a result of our research, it was observed that the falsification of documents was mostly committed by non-officials working in a particular enterprise, institution, but by employees - specialists working in the same enterprise. That is, the perpetrators of such a crime are persons who have the opportunity to obtain the stamp, seal and letterhead of the enterprise, institution, organization. Although they do not have the authority to issue or certify a particular official document, they have corrected a forged document using the stamp, seal, or letterhead of that enterprise, institution, organization, and selfgovernment body.

For example, a man named U worked as the head of the X-ray room and medical examination department at the central polyclinic in Besharik district in Fergana region and forged a medical certificate for $\mathrm{K}$., which is an official document exempting him from the cotton harvest. Using this forged document, $\mathrm{K}$. was exempt from participating in the cotton harvest. K. despite the fact that he was not ill with any disease, a false document was drawn up stating that he was suffering from rheumatism.

U.'s act was convicted under Article 228, Part 2, subparagraph (b), and $\mathrm{K}$ was convicted under Article 228, Part 3 [5].

Forged and falsified certain entitlement documents are different, ranging from a simple reference, which is an official 
document, to SSS employee's certificate, various certificates, diplomas, passports, and so on.

Another peculiarity of the crime under investigation is that almost half of the criminal cases we investigated were committed by a group of individuals with prior conspiracy. This can be seen from the following figures:

Only one person in the case accounts for $56 \%$ of those convicted. These are mainly individuals who have applied for the correction of a forged or falsified document and used it knowing that the document was forged. The number of criminal cases involving two people is $27 \%$, three people are $12 \%$, four people are charged with $2.2 \%$, and five or more people are charged with $3.9 \%$.

Another peculiarity of the crime under investigation is that almost half of the criminal cases we investigated were committed by a group of individuals with prior conspiracy. This can be seen from the following figures:

Only one person in the case accounts for $56 \%$ of those convicted. These are mainly individuals who have applied for the correction of a forged or forged document and used it knowing that the document was forged. The number of criminal cases involving two people is $27 \%$, three people are $12 \%$, four people are charged with $2.2 \%$, and five or more people are charged with $3.9 \%$. Our study found that the number of cases of this crime committed by an organized criminal group or criminal community was much lower, including less than one percent committed by an organized criminal group, and only two cases committed by a criminal community.

In general, the share of women in crime is very small. But in the crime we studied, the opposite is the case, however, $20.5 \%$ of the people accused of committing this crime are women.

In recent years, the active participation of women in society is characterized by an increase in their contribution to the commission of this crime. The women were mainly charged with the use of documents exempt from certain obligations. This means that women are more likely to be involved in document-related crimes than those who have committed other types of crimes. The women accused of this crime mainly used falsification of documents when there was a need to do something, when there was a financial shortage in the family (for example, exemption from the cotton harvest, receiving benefits for low-income families, etc.).

Among the women convicted under Article 228, which we examined, there were no previous convicts for any crime, no dangerous and extremely dangerous recidivists, no repeat offenders. The vast majority of women who commit this crime are married or a member of a particular family. The vast majority of those convicted under Article 228 of the Criminal Code are women who have pleaded guilty, expressing remorse for their actions. From what has been said, it is clear that there is a need to do more to explain the laws in force in the neighborhoods, in the offices of citizens' assemblies, among women.

According to the results of our research, a forged or falsified official document that gives a certain right and exempts from a certain obligation is a certificate. $44 \%$ of the 300 criminal cases convicted under Article 228 and other articles of the Criminal Code of the Republic of Uzbekistan constitute forgery of such certificates.

The following information show which types of forged or falsified official documents are used:

Various certificates - 8.6\%;

Various diplomas - 7.5\%;

Various blanks - 12.2\%;

Sanitary book or medical documents $6.4 \%$

References - 44\%;

Driving licenses - 2.2\%; 
Car documents - 2.9\%;

Tickets - 2.2\%;

Customs declaration - 3.6\%;

Passports - 3.9\%.

We would like to emphasize that daily life observations should not lead to the idea that the information we provide is accurate and conclusive from the information provided through the media. These figures are those charged under Article 228 of the Criminal Code of the Republic of Uzbekistan and other articles as a total of crimes and convicted in court. But there are many people who use forged or falsified document to achieve their goal and they are not exposed.

There are so many latent crimes have been committed by the police or prosecutors, even those who have been extorted using fake SSS documents but have not yet been exposed. Latent crime includes the sum of crimes that were not included in the statistical analysis due to the lack of official data [6. 140] .

In other words, latent crimes are crimes that are actually committed, but for some reason are not included in the list of law enforcement authorities.

In these crimes, the presence of kinship, acquaintances and in some cases, the material interest between the issuers and users of such forged or falsified stamps, seals or forms leads to high latency.

The saddest thing is that when a person sees that a person has prepared or used a forged orfalsified document, he or she is often indifferent to it, treats it as a normal situation, does not take it seriously, and finally fails to get rid of dependency. The prevalence of latency in the analyzed crime is due to the fact that under the pretext of any form of exercise of their rights or obligations, including the attempt to exercise them in a criminal way, has been formed.

According to the results of the study, preparation of forged documents, sale, use, fabrication of official documents that give a certain right or release from a certain obligation were as follows: $16.1 \%$

Preparation of forged documents -

Falsifying - 48.5\%;

Sales - $2.2 \%$;

Manufacturing sales $-4.7 \%$.

If we look at these data, the use of fake or forged documents is only $26.1 \%$. In fact, almost $92 \%$ of the individuals we surveyed used such a document, but the proportion of those qualified by only part 3 of Article 228 of the $\mathrm{CC}$ was $26.1 \%$.

Of course, while these indicators may not reflect the exact truth, they can be somewhat a resource in thinking about these issues and in developing crime prevention measures under analysis.

Any person who forges or falsifies any document will certainly set a specific goal for himself. Such a goal would be to acquire property in a criminal way, to have a certain right, or to be released from a certain obligation.

According to the results of our study, the subjects committed crimes under Article 228 of the Criminal Code of the Republic of Uzbekistan in order to achieve various district goals.

The criminal offenses of the persons investigated for the purpose of the subjects included:

Tax evasion (Article 184 of the Criminal Code) - 2.5\%;

Embezzlement and misappropriation (Article 167 of the Criminal Code of the Republic of Uzbekistan) - 15.5\%;

Career forgery (Article 209 of the Criminal Code) - 5.2\%;

Fraud (Article 168 of the Criminal Code) - 22.5\%;

Violation of customs legislation (Article 182 of the Criminal Code) - 2.1\%;

Exceeding the authority or position (Article 207 of the Criminal Code) - 1.9\%; 
Illegal departure abroad (Article 223 of the Criminal Code) - $1.5 \%$;

Refusal from military or alternative service (Article 225 of the Criminal Code of the Republic of Uzbekistan) - 1.2\%;

Abuse of power or position (Article 205 of the Criminal Code) $-3.6 \%$.

Falsification and forge of documents for the purpose of criminal community, aggression, unlawful acquisition or transfer of currency values, abuse of power or official position, exploitation of people, their recruitment, etc., account for less than $1 \%$ of those surveyed.

From the above data, it can be seen that the highest number of fraud crimes was committed through forgery or falsification of documents $(22.5 \%)$; then the crime of embezzlement and misappropriation was committed (15.5\%). Of course, this information does not fully reflect the real situation. Because the secrets of the people we investigated (500 people) have been revealed, the criminal case has been tried in court and they are the only people we have investigated. But even so, this information requires an understanding of the purpose of retraining and falsifying documents, certain service parts, and regulating the activities of employees.

$15.5 \%$ of the people we surveyed falsified documents in order to commit the crime of embezzlement and misappropriation. It is obvious that some property working in enterprises, institutions, organizations has been entrusted, and a new attitude to property has not yet been sufficiently formed in the persons who are financially responsible for this property.

Attitudes toward another's property or common property have not changed.

Shortcomings in the control of the accounting and reporting system by the head, indifference to the selection of officials in the field of material responsibility, shortcomings in the calculation of standards for the use of raw materials, the emergence of unrecorded raw materials and supplies, etc., can lead to corruption by officials, looting of property by falsification of documents.

In addition, shortcomings in the work of legal education are associated with the unpreparedness of lower-level management and the population, in particular, to solve complex management tasks based on the new economic ideology. Another important aspect is the lack of democratic management of economic processes.

Non-compliance, which is caused by coercion outside the economy and the abolition of the form of administrative management of the economy, can lead to looting through falsification or forgery of documents. Of the 500 individuals surveyed, only $15.5 \%$ committed the crime under Article 167 of the Criminal Code through falsification of documents.

\section{Conclusion}

Only $23.5 \%$ of the individuals we surveyed were qualified and prosecuted under Article 228 of the Criminal Code itself. Most of them are persons who have been prosecuted for the use of a forged or falsified document itself (Article 228, paragraph 3) or for the use of a document that exempts them from any other noncriminal obligation or for the purpose of using a forged document.

The individuals we surveyed:

$16.1 \%$ - in the preparation of forged documents;

$48.5 \%$ - when falsifying a document;

$26.1 \%$ - in use;

$4.7 \%$ - in the production and sale of forged documents;

$2.2 \%$ were prosecuted only for selling.

This information is the information about disclosed and the criminal case has seen in court and cannot be claimed as accurate information. However, documents, stamps, seals, letterheads, and other types of misconduct may have an understanding of the crime and may be important in developing measures to prevent such crimes. 
Thus, official documents, stamps, seals, letterheads are a political medium between enterprises, organizations and institutions, as well as between citizens and government agencies, and play an important role in all spheres of public life. Illegal treatment of them can undermine the system of government, lead to the looting of property, harm the rights and interests of citizens, and ultimately hinder the implementation of reforms to form a new democratic state based on the rule of law.

\section{References}

[1] Usmonaliev M., Karaketov Y. Criminology. Tashkent: Yangi asr avlodi, 2001. - p.163.
[2] Kudryavtsev V.N. Causality in criminology. Moscow: 1969.-p. 1819.

[3] Pinkhasov B.I. Protection of documents under Soviet law. Tashkent: Uzbekistan, 1976. -p. 104.

[4] From the archive material of the criminal court of Mirzo Ulugbek district of Tashkent. Jinoyat Criminal Case No. 1605/14. 2014.

[5] From the archive materials of the Criminal Court of Besharik district of Fergana region. №Criminal Case No. 1431/15. 2015.

[6] Usmonaliev M., Karaketov Y. Criminology. Tashkent: Yangi asr avlodi, 2001. - p.140. 